УДК 001.894

DOI: $10.33764 / 2687-041 X-2021-3-210-212$

\title{
ОСНОВЫ РАЗРАБОТКИ ТЕХНОЛОГИИ ИНВЕНТАРИЗАЦИИ ЗЕМЕЛЬНО-ИМУЩЕСТВЕННОГО КОМПЛЕКСА МУНИЦИПАЛЬНОГО ОБРАЗОВАНИЯ
}

\section{Дарина Сергеевна Шулбаева}

Сибирский государственный университет геосистем и технологий, 630108, Россия, г. Новосибирск, ул. Плахотного, 10, обучающийся, тел. (902)468-44-87, e-mail: dshulb@mail.ru

В статье рассмотрены основы высокоточных технологии геоинформационных систем, применяемых для инвентаризации земельно-имущественного комплекса. Эффективность ГИС-программ. Проводится описание этапов проведения инвентаризации земельно-имущественного комплекса муниципального образования. Методы исследования - индукция, аналитический метод

Ключевые слова: муниципальное образование, инвентаризация, земельно-имущественный комплекс, технология

\section{BASES FOR DEVELOPMENT OF INVENTORY TECHNOLOGY OF LAND-PROPERTY COMPLEX OF MUNICIPAL EDUCATION}

\section{Darina S. Shulbaeva}

Siberian State University of Geosystems and Technologies, 10, Plakhotnogo St., Novosibirsk, 630108, Russia, Student, phone: (902) 468-44-87, e-mail: dshulb@mail.ru

The article discusses the basics of high-precision technology of geographic information systems used for inventory of land and property complex. The effectiveness of GIS programs. The description of the stages of the inventory of the land and property complex of the municipality is carried out. Research methods - induction, analytical method.

Keywords: municipal formation, inventory, land and property complex, technology

Развитие информационных технологий сегодня значительным образом упрощает процесс инвентаризации земельно-имущественного комплекса муниципального образования.

При разработке технологии инвентаризации на территории муниципальных образований в Новосибирской области используются технические решения для дистанционного зондирования земли [1].

Это позволяет получить со спутников снимки с высоким разрешением и максимальной погрешностью, которая составляет 0,5 м. Эти данные используются составления цифровых карт с наложением на них картографических данных, собранных в ходе ручной работы и при использовании снимков со спутников. Метод наложения одной карты на другую позволяет выявить отклонения и создать 3D-карту с актуальными данными. Данные по картографической съемке используются для указания на карте сведений об объектах и их местонахождении, для указания координат и других существенных характеристик, необходимых для их учета в ходе инвентаризации. 
Применение результатов спутниковой съемки необходимо для обеспечения актуальной информацией специалистов, ответственных за проведение инвентаризации. Данные съемки используются для уточнения или же установления местоположения объектов, для установления границ объектов на карте, для определения рационально используемых земель и тех участков, которые используются нерационально и не в соответствии с установленной категорией землепользования [2].

Технология инвентаризации разрабатывается на подготовительном этапе перед проведением инвентаризации. Данные дистанционной съемки со спутников используются как для составления карт и актуализации данных, так и для последующей оценки результатов инвентаризации.

Обработка данных спутниковых снимков специалистами в области землеустройства и кадастрового учета ведется с использованием ГИС-программ. Функционал данных программ прост и удобен в использовании. Так, на основе данных спутниковой съемки и ГИС-программы осуществляется сбор первичных данных, на основе этого утверждается план проведения инвентаризационных работ. Чаще всего для разработки и использования технологии инвентаризации применяются спутниковые снимки с разрешением до 0,5 м. Аэрофотоснимки в настоящее время собираются с квадрокоптеров и только в отношении тех земельных участков и объектов, данные по которым в ходе спутниковой съемки нельзя получить в высоком разрешении [3].

Применение данных спутниковой съемки носит разнообразный характер, необходимо для подготовки планово-картографических материалов и информационного обеспечения рабочей группы, занятой инвентаризацией. Единственный минус спутниковых технологий съемки с разрешением до 20 м заключается в том, что с ними не обеспечивается точность определения линейных параметров объектов. Данные спутниковой съемки в муниципальных образованиях Новосибирской области используются для подготовки рабочих схем, а в процессе осуществления земельного контроля - для мониторинга использования земель сельскохозяйственного назначения. Спутниковые снимки с высоким разрешением используются как топографогеодезическая основа для последующей инвентаризации земель [4].

Снимки, полученные со спутников, содержат визуальное отображение местоположения объектов в пространстве, а также позволяют измерить площадь конкретного участка, установить его границы и т. д. В настоящее время ведется большая работа по оцифровке тех данных, которые были собраны за годы предыдущей работы и сбора данных с применения только созданных от руки карт и схем. Квадрокоптеры используются на этапе подготовки к инвентаризации лишь в отдельных случаях, к примеру, при изменении границ муниципального образования и необходимости уточнения данных по площади земельных участков сельскохозяйственного назначения.

Технология инвентаризации имущественно-земельного комплекса разрабатывается в несколько этапов. Во-первых, это изучение местности и подготовка карт с актуальными данными на основе обработки данных спутниковой съемки 
в ГИС-программе. Во-вторых, это разработка плана инвентаризации на основе составления перечня объектов, подлежащих учету в ходе инвентаризации. В-третьих, это планирование полевых работ с использованием и актуализацией геодезической базы непосредственно на местности. В-четвертых, это разработки технических условий под использование квадрокоптеров в той местности, данные по которой в ходе съемки нельзя получить в высоком разрешении или находящейся в труднодоступном районе. В-пятых, это утверждение перечня цифровых технологий и средств, подлежащих использованию в ходе инвентаризации. Методическими требованиями предусматриваются условия для их использования, требования к техническим характеристикам, допустимой погрешности и т. д. В-шестых, это утверждение плана по автоматизированной и ручной обработке полученных данных в ходе инвентаризации, актуализации информации по объектам в информационной базе.

Технологии 3D-моделирования пока не получили широкого распространения при подготовке и проведении инвентаризации. Однако и описанная технология предъявляет определенные требования к ресурсам, средствам и знаниям специалистов в области землеустройства и кадастрового учета. В сравнении с обычной ручной работой и использованием карт и схем, созданных в ходе полевых работ, описанная технология является перспективной для использования, позволяет сокращать сроки на проведение главной работы - подготовки к инвентаризации на основе актуализации картографических данных по земельным участкам и объектам, расположенным на них.

\section{БИБЛИОГРАФИЧЕСКИЙ СПИСОК}

1. Волков С.Н., Комов Н.В., Хлыстун В.Н. Как достичь эффективного управления земельными ресурсами в России? // Международный сельскохозяйственный журнал. 2015. № 3. C. 3-7.

2. Семочкин В.Н., Афанасьев П.В., Захарова О.В. Инвентаризация земель как информационная основа принятия управленческих решений по организации использования земель сельскохозяйственного назначения // Землеустройство, кадастр и мониторинг земель. 2018. № 3 (158). С. 18-23.

3. Жигулина Т.Н., Мерецкий В.А. Методические аспекты проведения инвентаризации земель сельскохозяйственного назначения, используемых сельскохозяйственными организациями // Вестник Алтайского государственного аграрного университета. 2016. № 8 (142). C. 84-88.

4. Панова А.А., Яроцкая Е.В Инвентаризация как метод учета земель // Студенческие научные работы инженерно-землеустроительного факультета: сборник статей по материалам студенческой научно-практической конференции. Краснодар: Кубанский государственный аграрный университет им. И.Т. Трубилина, 2017. С. 89-94.

(С Д. С. Шулбаева, 2021 